\section{PERANAN INTERNAL AUDIT DALAM PENGENDALIAN INTERNAL PIUTANG PADA PT. POS INDONESIA PERSERO CABANG DEPOK}

\author{
Marina Fatimatuzzahro dan Edy Sudaryanto \\ Program Studi Akuntansi, Institut Bisnis dan Informatika \\ Bogor, Indonesia \\ Email :lemlit@stiekesatuan.ac.id
}

Peranan Internal Audit Dalam

Pengendalian

Internal Piutang

Pada PT. Pos

Indonesia

Persero Cabang

Depok

\section{ABSTRACT}

Internal Audit functions to assess the results of the activities of an organization. The assessment consists of assessing organizational structure, planned activities, policies, employee performance, and compliance with procedures. Internal Audit is needed in organizations or companies that are engaged in production and services, to direct the company's operations, prevent the use of the system, and protect accounts receivable. Internal audit works independently on the company by conducting checks and evaluations that produce suggestions in the form of improvements to the management and control of the entities examined in this case are receivables.

The purpose of this study was to find out how the role of internal audit, to solve problems and the efforts made in internal control of receivables at PT. Pos Indonesia Persero Depok Branch.

The research method used is descriptive qualitative, by collecting data related to existing problems in the company, in accordance with the basics of the theory studied. Data collected, used to solve existing problems.

The results of the study show that internal audit implementation at PT. Pos Indonesia Persero Depok Branch has been good, so the control of accounts receivable has been running properly. Supervision of the company's performance must continue to be carried out by the internal audit so that there are no violations and improvements to the audit results are carried out according to input from the Internal audit. In addition, the internal audit should understand the activities of the auditee (the audited party), so that in conducting the audit as expected.

Keywords: Internal, Audit, Control, Receivables.

\section{PENDAHULUAN}

PT. Pos Indonesia merupakan Badan Usaha Milik Negara yang mendedikasikan usahanya pada pemanfaatan insfrastruktur jejaring yang dimiliki, saat ini mencapai sekitar 24 ribu titik layanan dan menjangkau 100 persen kota/kabupaten, hampir 100 persen kecamatan dan 42 persen kelurahan/desa, dan 940 lokasi transmigrasi terpencil di Indonesia.

Seiring dengan berjalannya waktu, PT. Pos Indonesia (PT. PI) kini telah mampu menunjukkan kreatifitasnya dalam pengembangan bidang perposan Indonesia. Umumnya setiap perusahaan memerlukan bagian khusus yang disebut bagian internal audit. Internal audit dirancang untuk menganalisis, menilai, meninjau ulang dan mengevaluasi hasil kinerja perusahaan. Dalam pelaksanaannya bagian internal audit memerlukan sumber daya manusia yang telah dipilih secara objektif dan mempunyai kualifikasi sesuai dengan bidangnya, seperti : terampil, cakap dan memiliki integritas dan kejujuran. Bagian ini bertugas mengawasi dan mengevaluasi keefektifan setiap aktivitas pengendalian yang ada dalam perusahaan dan menjaga agar seluruh prosedur dan penentuan yang berlaku di perusahaan dilaksanakan sebagaimana mestinya.
301

Submitted: MEI 2019

Accepted: OKTOBER 2019

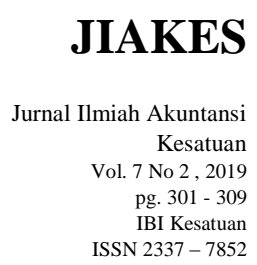


Peranan Internal Audit Dalam

Pengendalian

Internal Piutang

Pada PT. Pos

Indonesia

Persero Cabang

Depok

302
Internal audit merupakan aktivitas pemeriksaan dan penilaian independen yang dilaksanakan melalui pengendalian internal dan berfungsi sebagai alat yang digunakan auditor untuk mengumpulkan informasi. Pengawasan secara tidak langsung diciptakan untuk memberikan jaminan yang memadai atas perlindungan aktiva perusahaan. Pengendalian internal digunakan perusahaan untuk mengarahkan operasi perusahaan, mencegah penyalahgunaan sistem yang diterapkan, dan melindungi aktiva yang dimiliki perusahaan. Salah satu aktiva yang berperan dalam operasi perusahaan adalah piutang. Sistem pengelolaan piutang yang efektif akan mempengaruhi keberhasilan suatu perusahaan dalam menjalankan kebijakan penjualan barang atau jasa secara kredit. Sebaliknya, jika pengelolaan piutang tidak berjalan dengan efektif yaitu lemahnya kebijakan pengumpulan dan prosedur penagihan piutang, tentu nantinya akan menimbulkan resiko piutang tak tertagih (bad debt).

Untuk itu internal audit yang bekerja secara independen pada perusahaan harus melakukan pemeriksaan dan pengevaluasian yang menghasilkan saran berupa perbaikan akan pengelolaan dan pengendalian atas entitas yang diperiksa, dalam hal ini adalah piutang. Sistem pengelolaan dan pengendalian piutang yang baik adalah upaya untuk lebih meningkatkan kinerja keuangan untuk menekan biaya-biaya terutama yang berkaitan langsung dengan pengelolaan piutang seperti penyisihan piutang, penagihan piutang (yang bermasalah) dan penghapusan piutang.

Berdasarkan uraian diatas, perlu dilakukan penelitian yang terkait dengan peranan internal audit dalam pengendalian internal piutang pada PT. Pos Indonesia (Persero) cabang Depok.

\section{TINJAUAN PUSTAKA}

Definisi internal audit menurut Konsorsium Organisasi Profesi Audit Internal (2006, 9) adalah : Kegiatan assurance dan konsultasi yang independen dan obyektif, yang dirancang untuk memberikan nilai tambah dan meningkatkan kegiatan operasi organisasi. Audit internal membantu organisasi untuk mencapai tujuannya, melalui suatu pendekatan yang sistematis dan teratur untuk mengevaluasi dan meningkatkan efektivitas pengelolaan proses governance.

Definisi internal audit menurut Sukrisno Agoes $(2014,4)$ adalah : suatu pemeriksaan yang dilakukan secara kritis dan sistematis, oleh pihak- pihak yang independen, terhadap laporan keuangan yang telah disusun oleh manajemen, beserta catatan-catatan pembukuan dan bukti-bukti pendukungnya, dengan tujuan untuk dapat memberikan pendapat mengenai kewajaran laporan keuangan.

Menurut Hiro Tugiman $(2006,99)$ tujuan internal audit dapat diartikan sebagai berikut : membantu para anggota organisasi agar dapat melaksanakan tanggung jawabnya secara efektif. Untuk hal tersebut, auditor internal akan memberikan berbagai analisis, penilaian, rekomendasi, petunjuk, dan informasi sehubungan dengan kegiatan pemeriksaan. Tujuan pemeriksaan intern mencakup pula usaha mengembangkan pengendalian yang efektif dan wajar.

Tujuan internal audit adalah memberikan pelayanan kepada organisasi untuk membantu semua anggota organisasi tersebut. Bantuan yang diberikan sebagai tujuan akhir agar semua organisasi dapat melakukan semua tanggung jawab yang diberikan dan dibebankan secara efektif. Internal audit membantu manajemen dalam mencari kemungkinan yang paling baik dalam penggunaan sumber modal secara efisien dan efektif, termasuk efektivitas pengendalian dalam biaya yang wajar. Semua bantuan internal tersebut diberikan melalui analisis-analisis penilaian, saran-saran, bimbingan, dan informasi tentang aktivitas yang diperiksa. 
Secara umum, fungsi internal audit dalam perusahaan adalah untuk mengawasi atau menjamin pelaksanaan kegiatan agar sesuai dengan ketentuan-ketentuan yang telah ditetapkan dalam perusahaan. Internal audit sebagai staff pimpinan perusahaan yang khusus menangani masalah audit internal harus dapat bertugas dengan baik, sehingga peranannya dalam menunjang keberhasilan struktur pengawasan intern berlangsung dengan optimal. Internal audit juga bertugas melakukan pemeriksaan dan penilaian yang bebas atas kegiatan operasional, data akuntansi dan catatan keuangan lainnya.

Sedangkan Fungsi internal audit menurut Konsorsium Organisasi Profesi Audit Internal $(2006,20)$ mengemukakan bahwa fungsi audit sebagai peningkatan proses pengelolaan risiko, pengendalian, dan governance, dengan menggunakan pendekatan yang sistematis, teratur dan menyeluruh.

Sukrisno Agoes $(2014,100)$ mendefinisikan pengendalian internal sebagai : internal melakukan evaluasi dan memberikan kontribusi terhadap suatu proses yang dijalankan oleh dewan komisaris, manajemen dan personil lain, entitas yang didesain untuk memberikan keyakinan memadai tentang pencapaian tiga golongan tujuan berikut : (a) keandalan pelaporan keuangan, (b) efektivitas dan efisiensi operasi, dan (c) kepatuhan terhadap hukum dan peraturan yang berlaku.

Menurut PP 60 tahun 2008 pasal 1, menyebutkan bahwa pengendalian internal adalah : seluruh proses kegiatan audit, review, evaluasi, pemantauan, dan kegiatan pengawasan lain terhadap penyelenggaraan tugas dan fungsi organisasi dalam rangka memberikan keyakinan yang memadai bahwa kegiatan telah dilaksanakan sesuai dengan tolok ukur yang telah ditetapkan secara efektif dan efisien untuk kepentingan pimpinan dalam mewujudkan tata pemerintahan yang baik.

Pengendalian internal menurut Akmal (2006, 25) memiliki lima unsur, yaitu 1) lingkungan pengendalian, 2) penaksiran risiko, 3) aktivitas pengendalian, 4) informasi dan komunikasi, 5) pemantauan.

Menurut Mulyadi $(2002,165)$ pengendalian internal disusun berdasarkan tujuan untuk memberikan keyakinan yang memadai bahwa laporan keuangan disajikan secara wajar sesuai dengan prinsip akuntansi berterima umum di Indonesia.

Pengertian piutang menurut Michell Suharli (2006, 201) mengatakan : piutang mencakup semua tagihan dalam bentuk uang kepada perseorangan, badan usaha atau pihak tertagih lainnya. Artinya, pihak lain yang berhutang kepada perusahaanperusahaan. Sebagian besar jumlah piutang umumnya timbul dari transaksi penjualan barang/jasa secara kredit. Sebagian lain timbul dari pinjaman yang diberikan perusahaan seperti : karyawan, pemegang saham, dan perorangan lainnya.

Sukrisno Agoes $(2012,192)$ mendefinisikan piutang usaha sebagai piutang yang berasal dari penjualan barang dagangan atau jasa secara kredit.

Piutang merupakan hak atau klaim perusahaan terhadap klien atau pelanggan atas barang atau jasa yang telah diberikan.

Internal audit sangat membantu manajemen dengan mengevaluasi sistem pengendalian dan menunjukkan kelemahan-kelemahan dalam pengendalian internal. Bukti ketaatan terhadap kebijakan, prosedur, peraturan atau perundang-undang yang sudah ditetapkan baik oleh manajemen maupun pemerintah terletak pada pendokumentasian yang layak.

\section{METODE PENELITIAN}

Metode penelitian yang digunakan adalah metode deskriptif, adapun jenis dan sumber data yang digunakan dalam penelitian ini adalah :

1. Data Primer (Primary Data)
Peranan Internal Audit Dalam Pengendalian

Internal Piutang

Pada PT. Pos

Indonesia

Persero Cabang Depok

303 


\section{$\underline{304}$}

\section{Peranan Internal Audit Dalam \\ Pengendalian \\ Internal Piutang \\ Pada PT. Pos \\ Indonesia \\ Persero Cabang \\ Depok}

Data primer merupakan sumber data yang diperoleh secara langsung dari perusahaan. Data primer ini dapat berupa bukti, catatan atau laporan historis yang telah tersusun dalam arsip (data dokumenter) yang dipublikasikan maupun tidak dipublikasikan, observasi terhadap suatu benda (fisik), kejadian atau kegiatan, dan hasil pengujian.

2. Data sekunder (Secondary Data)

Data sekunder merupakan sumber data penelitian yang diperoleh peneliti dari buku atau riset kepustakaan.

Pengumpulan data penelitian ini menggunakan teknik sebagai berikut:

1) Dokumentasi

Dokumentasi adalah teknik pengumpulan data yang dilakukan kepada subjek penelitian dengan cara penulis mempelajari data-data yang didapat dari lembaga-lembaga yang terkait dengan materi penelitian.

2) Riset

Riset merupakan cara pengambilan data dengan pengamatan langsung yang dapat dilakukan dengan menggunakan seluruh alat indera dengan mengajukan pertanyaan atau komunikasi dengan individu-individu yang diteliti.

3) Riset kepustakaan

Riset Kepustakaan adalah metode pengumpulan data dengan cara menggunakan literatur (kepustakaan) baik berupa buku, catatan, maupun laporan hasil penelitian dari penelitian terdahulu.

\section{HASIL DAN PEMBAHASAN}

Berikut ini akan dijelaskan hasil penelitian yang terkait dengan peranan internal audit dalam pengendalian internal piutang sebagai berikut :

Fungsi dan peran yang dijalankan oleh internal audit adalah membantu kepala kantor dalam menjalankan fungsi pengawasan. Peranan internal audit perusahaan adalah menjaga agar semua Standar Operasional Prosedur (SOP) berjalan sesuai dengan aturan yang sudah ditetapkan oleh perusahaan, dimana aturan yang ada sudah berdasarkan keputusan direksi, surat edaran direksi, dan kepala kantor termasuk undang undang yang berlaku, dan peraturan pemerintah.

Dalam rangka meyakinkan pelaksanaan tugas pengawasan dan kepastian pencapaian tujuan pengawasan dari internal audit dalam pengendalian internal, maka perlu diyakinkan bahwa internal audit perusahaan sudah handal dan baik, dan didasarkan pada unsur-unsur pengendalian yaitu :

1. Lingkungan Pengendalian (Control environment)

Lingkungan pengendalian perusahaan terbagi menjadi 3 komponen, yaitu:

a) Integritas dan Nilai Etika

Prinsip integritas dan nilai etika sangat dijunjung tinggi oleh pemimpin perusahaan. Pemimpin perusahaan mengedepankan sikap profesionalisme kepada karyawan. Hal ini dapat dilihat dari nilai kejujuran yang telah diterapkan kepada setiap individu. Selain itu, dalam memilih karyawan yang akan bekerja, pimpinan sangat selektif. Hal ini bertujuan untuk menciptakan sumber daya yang berkualitas, yang dapat bekerja secara maksimal sesuai dengan keahlian di bidangnya masing-masing. Dan apabila ada karyawan yang melanggar peraturan yang telah ditetapkan oleh perusahaan, pemimpin perusahaan akan bertindak tegas dengan memberikan surat peringatan pertama kepada karyawan yang melanggar, apabila dari surat peringatan 
pertama, karyawan tersebut masih tidak mentaati peraturan, maka pemimpin perusahaan akan memberikan surat peringatan kedua, dan ketiga sampai karyawan tersebut diberikan sanksi tegas oleh perusahaan.

b) Struktur Organisasi

Struktur organisasi yang ada di perusahan secara umum sudah terdapat pemisahan tugas dan tanggung jawab yang disusun dengan jelas dalam setiap fungsi organisasi. Struktur organisasi pada perusahaan ini merupakan struktur organisasi tersentralisasi karena pengambilan keputusan dikonsentrasikan pada kepala kantor. Struktur organisasi perusahaan, menunjukkan setiap karyawan memiliki wewenang dan tanggung jawab masing-masing sesuai dengan posisi yang diisi.

c) Pendelegasian Wewenang dan Tanggung Jawab

Pendelegasian wewenang dan tanggung jawab disampaikan melalui tulisan, sehingga terdapat aturan baku yang perlu diikuti oleh karyawan. Aturan baku ini terdapat dalam SOP yang dibuat oleh manajemen sedemikian rupa untuk mengatur berbagai prosedur dalam menjalankan kegiatan operasional perusahaan.

\section{Penaksiran Risiko (Risk Assesment)}

Perusahaan telah melakukan beberapa upaya untuk mencegah terjadinya risiko dalam memberikan piutang. Salah satunya dengan melihat performance atau kelayakan mitra berdasarkan riwayat transaksi yang telah dilakukan. Apakah dalam transaksi tersebut mitra melakukan pembayaran dengan lancar atau sebaliknya. Selain itu, tidak semua mitra diberikan kredit, hanya mitra yang telah sering menggunakan jasa perusahaan, yang biasanya diberikan kredit. Hal itu dikarenakan perusahaan meminimalisasi kemungkinan terjadinya kerugian karena piutang tidak dapat tertagih.

Walaupun kebijakan perusahaan dalam memberikan kredit kepada mitra sudah dijalankan sesuai dengan aturannya, masih terdapat risiko yang perlu diperhatikan oleh perusahaan, diantaranya:

a. Kelengkapan

Perusahaan telah melakukan upaya pencegahan atas terjadinya risiko, yaitu dengan melengkapi dokumen-dokumen atas mitra yang memperoleh kredit seperti SPK, backsheet, lampiran invoice. Hal ini untuk memudahkan apabila dokumen tersebut suatu waktu akan digunakan.

b. Personel baru

Untuk meminimalisasi terjadinya risiko yang disebabkan oleh human error, perusahaan sangat selektif dalam merekrut sumber daya manusia yang akan bekerja di perusahaan. Selain itu perusahaan memberikan pelatihan/training kepada personel baru, selama tiga bulan, dengan tujuan sumber daya manusia tersebut dapat bekerja dengan baik.

3. Aktivitas Pengendalian (Control Activity)

Berdasarkan hasil riset, perusahaan melakukan aktivitas pengendalian terkait dengan kebijakan yang telah diterapkan dalam manajemen sebagai bentuk penilaian untuk memastikan bahwa arahan yang diberikan manajemen telah dilaksanakan. Berikut ini beberapa aktivitas pengendalian yang dilakukan oleh perusahaan meliputi :

1. Pelaksanaan Review

Pelaksanaan review atau peninjauan kembali yang dilakukan yaitu dengan cara meninjau kembali kegiatan penjualan pada perusahaan. Dalam kegiatan
Peranan Internal Audit Dalam Pengendalian Internal Piutang

Pada PT. Pos Indonesia

Persero Cabang Depok

305 
Peranan Internal Audit Dalam

Pengendalian

Internal Piutang

Pada PT. Pos

Indonesia

Persero Cabang

Depok

\section{$\underline{306}$}

ini perusahaan membandingkan tingkat penjualan kredit yang telah terjadi dengan target pencapaian yang telah ditetapkan sebelumnya.

2. Otorisasi transaksi dan kegiatan

Perusahaan telah menetapkan dalam SOP mengenai pengotorisasian dengan cukup jelas. Dalam SOP tersebut dijelaskan bahwa pengotorisasian dilakukan oleh orang yang memiliki wewenang terhadap jabatan dan fungsinya sebagai pemberi persetujuan dalam kegiatan operasional perusahaan.

3. Pemisahan tugas

Pengendalian internal dikatakan baik apabila memiliki struktur organisasi yang baik. Struktur organisasi dikatakan baik apabila terdapat pemisahan tugas dan tanggung jawab fungsional yang baik pula. Dalam hal ini perusahaan telah menerapkan pemisahan tugas yang cukup baik, hal tersebut dilihat dari:

a. Fungsi penjualan terpisah dari fungsi piutang

Perusahaan telah memisahkan antara fungsi penjualan dengan fungsi piutang. Fungsi penjualan dilakukan oleh bagian pemasaran dan fungsi piutang dilakukan oleh bagian piutang.

b. Fungsi akuntansi terpisah dengan fungsi kas

Perusahaan telah melakukan pemisahan fungsi akuntansi dengan fungsi penerimaan kas.

c. Fungsi akuntansi terpisah dari fungsi penjualan dan fungsi piutang Perusahaan sudah memisahkan antara fungsi akuntansi, fungsi penjualan, dan fungsi piutang.

4. Informasi dan Komunikasi

Perusahaan telah memiliki sistem akuntansi yang cukup memadai yang terdiri atas metode dan catatan yang dibangun untuk mencatat, mengolah, meringkas dan melaporkan transaksi entitas dan untuk memelihara akuntabilitas bagi aset, utang, dan ekuitas perusahaan. Semua sistem tersebut secara keseluruhan sudah terkomputerisasi, sehingga risiko terjadinya kesalahan terkait dengan piutang dapat dengan mudah ditelusuri dimana letak kesalahannya.

5. Pemantauan (Monitoring)

Pemantauan sangat penting dalam kegiatan yang berkaitan dengan penjualan. Hal ini dikarenakan kegiatan penjualan merupakan penghasil laba yang paling besar dalam perusahaan, khususnya penjualan kredit sehingga memerlukan pemantauan atau pengawasan yang lebih. Berdasarkan hasil riset yang dilakukan pada kegiatan penjualan kredit diawasi oleh kepala kantor secara langsung, berikut diantaranya:

a. Merencanakan, mengkoordinasikan dan mengontrol arus kas perusahaan, terutama pengelolaan piutang dan hutang perusahaan, sehingga memastikan ketersediaan dana untuk operasional perusahaan.

b. Mengkoordinasikan penyelesaian piutang yang sulit ditagih atau piutang macet ke antar pemimpin perusahaan.

Dalam mengelola piutangnya, perusahaan perlu membuat suatu kebijakan dalam memberikan kredit kepada pelanggannya. Kebijakan ini berfungsi sebagai standar untuk menentukan kriteria pelanggan yang layak untuk diberikan kredit. Kebijakan tersebut dibuat agar output dan tujuan yang diharapkan dapat mencapai sasaran yang ditentukan perusahaan. Adapun pengelolaan piutang di kantor pos Depok dapat dibagi kedalam dua bagian yaitu : 1) Jenis dan Objek Piutang Dagang 2) Kebijakan Kredit.

Prosedur pemeriksaan piutang di kantor pos Depok oleh internal audit dilakukan dengan cara : 
Mengambil salah satu sample perusahaan mitra yang berpiutang dengan Kantor Pos Depok

$>$ Memeriksa hasil entry kiriman (Backsheet kiriman) dengan pertanggungan keuangannya di neraca petugas entry. Mencocokkan jumlah besar uang dan jumlah transaksi, jika sama, dibubuhi paraf pemeriksaan. Setelah itu neraca tersebut dicocokkan dengan pembukuan di bagian akuntansi sehingga terjadi saling pencocokkan antar bagian.

$>$ Memeriksa invoice yang dibuat oleh bagian piutang dan dicocokkan dengan total tagihan pada buku pengawasan dan kembali dicocokkan dengan bagian akuntansi.

> Melakukan pengawasan pembayaran atas piutang yang dilakukan oleh mitra yang dilakukan secara transfer ke rekening kantor yang diawasi oleh bagian keuangan

> Karena terkait dengan bagian keuangan, maka diperiksa rekening koran bank yang bertalian dan juga pembukuannya pada neraca kasir dibagian keuangan.

Hasil audit dari temuan bagian internal audit pada kegiatan operasional dalam hal ini pada bagian piutang, setelah melaksanakan audit di bagian terkait, membuat laporan dalam bentuk format yang sudah ditetapkan di kantor pos kemudian ditujukan ke kantor pos pusat di Bandung dan kemudian di tandatangani oleh bagian internal audit dan kepala kantor pos Depok yang isinya adalah berupa temuan-temuan hasil audit beserta saran dan komitmen serta komitmen tindak lanjut.

Pada umumnya piutang yang ada di perusahaan adalah piutang lancar. Namun, dikarenakan adanya limpahan piutang dari kantor pos Sawangan yang dimerger oleh kantor pos Depok maka piutang yang didapat dari kantor pos Sawangan tersebut menjadi salah satu piutang yang tidak lancar. Hal ini disebabkan karena mitra perusahaan tersebut dinyatakan pailit dan permintaan dari mitra perusahaan tersebut pembayaran piutangnya secara menyicil namun mitra tersebut tetap tidak membayar. Penyebab lainnya, mitra perusahaan tersebut masih ada, namun dalam pembayaran piutangnya terlalu berbelit belit.

Atas kendala tersebut, maka upaya internal audit perusahaan merekomendasikan kepada petugas admin piutang untuk tetap melakukan penagihan dengan mengantarkan langsung invoice tersebut ke perusahaan. Selain itu, internal audit juga merekomendasikan manajer terkait untuk mendatangi dan bertemu dengan pimpinan perusahaan tersebut untuk mendapatkan penjelasan dan penyelesaian atas piutang tersebut. Bagi perusahaan yang dinyatakan pailit, internal audit menyarankan untuk tetap diusahakan penagihan walaupun dengan sistem dicicil dan membuat surat pernyataan bahwa apabila sudah benar-benar tidak dapat ditagih disarankan untuk membuat surat ke kantor pos pusat/regional agar diusulkan menjadi penghapusan piutang.

\section{SIMPULAN}

Berdasarkan pembahasan yang telah disampaikan, maka dapat disimpulkan bahwa :

1. Peranan internal audit perusahaan, sebagai pengawas atas keberlangsungan aktifitas perusahaan cukup baik.

2. Internal audit dalam struktur organisasi setara dengan manajer yang lain.

3. Adanya dukungan manajemen terhadap internal audit. Hal ini dibuktikan dengan adanya laporan hasil internal audit yang disampaikan kepada direktur. Laporan hasil audit ini memuat temuan-temuan hasil audit, saran perbaikan dan tindakan-tindakan perbaikan yang diusulkan. 
Peranan Internal

Audit Dalam

Pengendalian

Internal Piutang

Pada PT. Pos

Indonesia

Persero Cabang

Depok

\section{8}

4. Pengendalian internal piutang perusahaan sudah dilaksanakan dengan baik, hal ini didukung oleh :

a. Unsur- unsur yang terdapat pada lingkungan pengendalian yang ada telah memadai. Misalnya adanya struktur organisasi perusahaan yang disertai tugas dan tanggung jawab yang jelas pada masing-masing bagian.

b. Penaksiran risiko yang ditandai dengan adanya kelengkapan dokumen atas pemberian dan penagihan piutang kepada mitra dan juga sumber daya manusia yang memadai.

c. Aktifitas pengendalian yang dilaksanakan dalam mereview, pengotorisasian tugas, dan pemisahan tugas telah dilaksanakan dengan cukup baik.

d. Informasi dan komunikasi atas akuntansi sudah memiliki sistem akuntansi yang terkomputerisasi.

e. Pemantauannya terkait pengendalian internal piutang juga sudah terorganisir baik antara bagian pemasaran dan bagian piutang termasuk didalamnya ada pengawasan dari kepala kantor.

f. Kebijakan kredit yang diberikan untuk mengurangi risiko piutang tak tertagih dilakukan dengan adanya standar kredit, periode kredit, dan kebijakan penagihan.

g. Kendala internal audit dalam pengendalian internal piutang ada pada mitra yang perusahaannya pailit dan selalu minta tempo pembayaran dengan mencicil dan atau mitra yang pembayarannya terlalu berbelit- belit.

Upaya internal audit dalam mengatasi kendala tersebut adalah dengan dimintanya mitra yang dinyatakan pailit tersebut untuk membuat surat tertulis ke kantor pos pusat/ regional agar dapat dibantu sebagai penghapusan piutang. Dan bagi mitra yang masih dinyatakan ada namun pembayarannya berbelit-belit, maka disarankan agar antar pemimpin perusahaan yang menyelesaikan piutang tersebut.

\section{SARAN}

Berdasarkan simpulan diatas, maka beberapa saran yang dapat diberikan adalah sebagai berikut:

1. Pada penilaian risiko, perusahaan perlu membuat review terhadap pemberian fasilitas kredit kepada mitra. Sehingga risiko-risiko yang dapat menyebabkan terhambatnya penagihan piutang dapat diantisipasi.

2. Upaya penagihan terhadap piutang yang sulit ditagih sebaiknya lebih sering menggunakan cara yang tegas yaitu didatangi langsung ke tempat pelanggan. Walaupun cara ini memerlukan biaya tambahan, tetapi cara tersebut dinilai cukup efektif karena pelanggan biasanya langsung melunasi hutangnya.

3. Internal audit hendaknya melakukan audit secara berkala yaitu setiap bulan agar pelaksanaan kegiatan di kantor pos Depok terpantau dan berjalan sesuai dengan SOP yang berlaku.

\section{DAFTAR PUSTAKA}

Adisaputro, Gunawan. 2011. Anggaran Perusahaan. Edisi 2, BPFE, Yogyakarta. Agoes, Sukrisno. 2014. Auditing. Edisi 4, Salemba Empat, Jakarta

2012. Auditing (Pemeriksaan AKuntan) Oleh Kantor Akuntan

Publik. Jilid 1, Salemba Empat, Jakarta.

2011. Auditing (Pemeriksaan Akuntan) oleh Kantor Akuntan

Publik. Edisi 4.Salemba Empat, Jakarta. 
Akmal. 2006. Pemeriksaan Intern (Internal Audit), Indeks, Jakarta.

Andayani, Wuryan. 2008. Audit Internal. Edisi 1, BPFE Yogyakarta, Yogyakarta.

Arens, Alvin A. dan Loebbecke, James K. 2007. Auditing. Buku 5. Alih Bahasa: Amir Abadi Jusuf, Salemba Empat, Jakarta.

Arens, Alvin A. James L. Loebbecke. 2008. Auditing Pendekatan Terpadu. Buku Dua, Edisi Indonesia. Terjemahan oleh Amir Abadi Yusuf, Salemba Empat, Jakarta.

Gondodiyoto, Sanyoto dan Henny Hendarti. 2007. Audit Sistem Informasi, Edisi Revisi. Mitra Wacana Media, Jakarta.

Hery, S.E., M.Si. 2011. Auditing I (Dasar- dasar Pemeriksaan Akuntansi). Kencana Prenada Media Group. Jakarta

Ikatan Akuntan Indonesia. 2007. Standar Akuntansi Keuangan. Salemba Empat. Jakarta

Kurnia, Rahayu Siti dan Ely Suhayati. 2010. Auditing Konsep Dasar dan Pedoman Pemeriksaan Akuntan Publik. Graha Ilmu, Yogyakarta.

Peranan Internal Audit Dalam Pengendalian Internal Piutang Pada PT. Pos Indonesia

Persero Cabang Depok

Konsorsium Organisasi Profesi Audit Internal. 2006. Standar Profesi Audit Internal. Yayasan Pendidikan Internal Audit. Jakarta

Suharli, Michell. 2006. Akuntansi Untuk Bisnis Jasa dan Dagang. Graha Ilmu. Yogyakarta

Syamsudin, Lukman. 2007. Manajemen keuangan perusahaan. Raja Grafindo Persada. Jakarta

Tugiman, Hiro. 2006. Standar Profesional Audit Internal. Kanisius, Yogyakarta.

Thoha, Miftah dan Siswanto. 2012. Kepemimpinan Dalam Manajemen. Rajawali

Pers. Jakarta.

http://www.posindonesia.co.id/index.php/profil-perusahaan/organisasi/strukturorganisasi. Diakses pada 14 November 2016.

http://www.posindonesia.co.id/index.php/profil-perusahaan/sejarah-pos. Diakses pada 14 November 2016.

https://id.wikipedia.org/wiki/Pos_Indonesia. Diakses pada 14 November 2016.

https://karyatulisilmiah.com/pengertian-peranan/. Diakses pada 14 November 2016. http://globallavebookx.blogspot.co.id/2014/07/pengertian-test-of-control pengujian.html. Diakses pada 09 September 2017 